Original Article

\title{
Bioactive properties of Persea lingue Ness (Lauraceae) fruit and leaf extracts
}

\author{
Propriedades bioativas de extratos de folhas e frutos de Persea lingue Ness (Lauraceae)
}

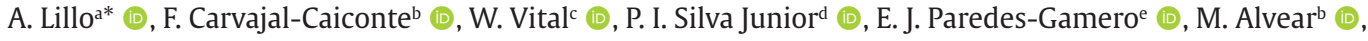 \\ and A. Miranda ${ }^{\mathrm{f}}$ (D) \\ aUniversidade Federal de São Paulo - UNIFESP, Departamento de Ciência e Tecnologia, São José Dos Campos, SP, Brasil \\ bUniversidad de La Frontera, Departamento de Ciencias Químicas y Recursos Naturales, Temuco, Chile \\ cUniversidade Federal de São Paulo - UNIFESP, Departamento de Biologia Química, Diadema, SP, Brasil \\ 'Instituto Butantan, Centro de Toxinas, Resposta Imune e Sinalização Celular - CeTICS, Centro de Pesquisa, Inovação e Difusão - CEPID, \\ Laboratório de Toxinologia Aplicada - LETA, São Paulo, SP, Brasil \\ eUniversidade Federal de Mato Grosso do Sul - UFMS, Faculdade de Ciências Farmacêuticas, Alimentos e Nutrição, Campo Grande, MS, Brasil \\ fUniversidade Federal de São Paulo - UNIFESP, Departamento de Biofísica, São Paulo, SP, Brasil
}

\begin{abstract}
Persea lingue Ness is a tree species that lives mainly in temperate forests of south-central Chile. Its leaves are used in ethnomedicine, the fruit is a drupe similar to that of the avocado and has not been studied. The aim of this study was to determine the cytotoxicity in leukemia cell and antibacterial activity, along with some chemical content characteristics of $P$. lingue fruit and leaf extracts. The antibacterial activity was determined by the inhibition of bacterial growth in liquid medium assay against Gram-positive and Gram-negative bacteria. The leukemia cell lines Kasumi-1 and Jurkat were used to evaluate the cytotoxic activity by using propidium iodide and AlamarBlue assays. Total phenolic, flavonoid, condensed tannin, alkaloid and lipid contents were evaluated in the fruit and in the leaf extracts. The antioxidant activity of both extracts were also elavaluated. Leaf extract presented the highest content of total phenols, condensed tannins and flavonoids, and also the highest antioxidant activity. While the fruit extract has a higher amount of lipids and alkaloids and the high antibacterial activity against Escherichia coli, Pseudomonas aeruginosa, Staphylococcus aureus, Bacillus megaterium and Micrococcus luteus. The leaf extract only showed activity against $M$. luteus. Concerning the cytotoxic activity, only the fruit extract showed cytotoxicity against the cell lines Jurkat and Kasumi-1. P. lingue fruit extract is a potential source of biologically active molecules for the development of new drugs to be used in some types of leukemia, as well as antibacterial agent.
\end{abstract}

Keywords: Persea lingue, antibacterial activity, cytotoxic activity, secondary metabolite.

\begin{abstract}
Resumo
Persea lingue Ness é uma árvore que vive principalmente na floresta temperada do centro-sul do Chile. As folhas são usadas na etnomedicina. $\mathrm{O}$ fruto é uma drupa similar ao abacate e que nunca foi pesquisada anteriormente. $\mathrm{O}$ objetivo deste estudo foi o de avaliar a citotoxicidade em células leucêmicas e as atividades antibacterianas, assim como algumas características químicas do extrato de fruto e da folha do P. lingue. As atividades antibacterianas foram determinadas pelo método da inibição do crescimento bacteriano em meio líquido empregando-se bactérias Gram-positivas e Gram-negativas. As linhagens celulares leucêmicas, Kasumi-1 e Jurkat foram usadas para avaliar a atividade citotóxica em ensaios empregando-se iodeto de propídio e AlamarBlue. Foram avaliados os teores totais de fenóis, flavonóides, taninos condensados, alcalóides e lipídeos presentes nos extratos das folhas e dos frutos. As atividades antioxidantes de ambos os extratos também foram avaliadas. 0 extrato das folhas foi o que apresentou o maior conteúdo de fenóis, taninos condensados e flavonóides totais e a maior atividade antioxidante. Já o extrato de fruto apresentou a maior quantidade de lipídios e alcaloides e a melhor atividade antibacteriana contra Escherichia coli, Pseudomonas aeruginosa, Staphylococcus aureus, Bacillus megaterium e Micrococcus luteus. Já o extrato das folhas apresentou apenas atividade contra $M$. luteus. Em relação à atividade citotóxica, apenas o extrato do fruto apresentou citotoxicidade contra as linhagens celulares Jurkat e Kasumi-1. Em resumo, o extrato do fruto de $P$. lingue é uma potencial fonte de moléculas com atividade biológica para o desenvolvimento de novos fármacos a serem utilizados em alguns tipos de leucemia, bem como agente antibacteriano.
\end{abstract}

Palavras clave: Persea lingue, atividade antibacteriana, atividade citotóxica, metabolito secundário.

*e-mail: alexis.lillo@unifesp.br

Received: January 28, 2021 - Accepted: May 15, 2021

This is an Open Access article distributed under the terms of the Creative Commons Attribution License, which permits unrestricted use, distribution, and reproduction in any medium, provided the original work is properly cited. 


\section{Introduction}

The interest in searching for new chemical compounds biologically active has raised research on flora with a history of traditional folk medicine (Fulda and Efferth, 2015). The main goal is to develop new drugs against diseases such as cancer, diabetes, Alzheimer, among others; and also find new molecules with antibacterial activity due to antibiotic resistance and the lack of new antimicrobials (Elisha et al., 2017).

Vascular plants produce a wide variety of secondary metabolites, such as polyphenols, alkaloids, and terpenes (Delgoda and Murray, 2017). These compounds are used as protection mechanisms against phytopathogens, such as viruses, bacteria and fungi, also from herbivores and insect attack; as well as being antioxidants, free radical scavengers, UV light absorbers and antiproliferative agents (Fulda and Efferth, 2015; Wink, 2003; Kennedy and Wightman, 2011; Freiesleben and Jäger, 2014).

The species of the Lauraceae family have a wide variety of uses, ranging from spices to drugs (Palazzo et al., 2009). One of its main genera is Persea, with about 190 species distributed in the tropical and subtropical zones of America and Asia (van der Werff, 2002); highlighting the species Persea americana Mill. (avocado), reporting an important biological activity as antioxidant, antimicrobial, antitumor, antidiabetic and antimalarial (Lima et al., 2012; GuzmánRodríguez et al., 2013; Jesus et al., 2015), especially the fruit of this species, where they found different beneficial properties for human health (Yasir et al., 2010), including phytochemical compounds with potential in use for some types of cancer (Dreher and Davenport, 2013).

Persea lingue Ness, is a tree species up to 30 meters high and lives mainly in the temperate forests of south-central Chile, and its conservation status is of least concern (LC) in most of the Chilean territory according to the latest report of the Ministry of Environment (Chile, 2019). This plant, has been highly exploited in the past for the excellent quality of its wood used in the manufacture of fine furniture, and by the use of their husk, used in leather tanning due to its high tannin content (Donoso and Escobar, 2006; Cob et al., 2010); also has use in ethnomedicine by using its leaves to treat some diseases (Holler et al., 2012a, b). The study of compounds with chemical or medicinal properties of fruit, it is practically nil. The fruit of $P$. lingue is a drupe that resembles the fruit of the avocado, but of smaller size, with 14 to $17 \mathrm{~mm}$ in length and with 11 to $14 \mathrm{~mm}$ of diameter. It presents a violet color to bright black when ripe, with bitter taste, and serves as food mainly for avifauna, and local rodents (Vergara et al., 2010; GhoIllanes et al., 2015). As for human consumption, there are few reports, the Mapuche's, a people originally from Chile, formerly prepared an alcoholic beverage, "chicha", based on fermentation of their fruit (Pardo and Pizarro, 2016).

In order to find new extracts of plants with a pharmacological potential, the objective of this study was to determine the cytotoxicity against leukemia cells linkage and antibacterial activity, along with some chemical content characteristics of Persea lingue fruit and leaf extracts.

\section{Material and Methods}

\subsection{Plant material}

The fruit and leaf samples of $P$. lingue were collected in the Province of Cautín, Region of La Araucanía, Chile; identified by Dr. Alicia Marticorena and specimens were deposited at the Herbarium CONC (Universidad de Concepción) with register $\mathrm{N}^{\circ} 189838$. They were washed with distilled water and dried at $30 \pm 2{ }^{\circ} \mathrm{C}$ for $72 \mathrm{~h}$. The samples were ground for further maceration. The maceration was performed with $10 \mathrm{~g}$ of dry material in $50 \mathrm{~mL}$ of methanol, the resulting solution was sonicated for $15 \mathrm{~min}(\times 3)$. Subsequently, the blend was filtered on Whatman No. 1 paper and the solvent eliminated on a rotary evaporator (BÜCHI R-210) at reduced pressure and at a temperature of $40{ }^{\circ} \mathrm{C}$, finally the resulting sample was lyophilized.

\subsection{Chemical analysis}

\subsubsection{Liquid chromatography/electrospray mass spectrometry (LC/ESI-MS)}

LC/ESI-MS data were obtained on a mass spectrometer model 3100 coupled to a liquid chromatograph model Alliance 2695 both from Waters (Milford, MA, USA) using a Phenomenex (Torrance, CA, USA) Gemini $C_{18}$ column (2.0 mm $\times 150 \mathrm{~mm}, 3.0 \mu \mathrm{m}$ particle size, and $110 \AA$ pore size). Solvent A was $0.1 \%$ TFA in water, and solvent B was $90 \%$ methanol in solvent $A$. The gradient was $5-95 \%$ B for $30 \mathrm{~min}$, and molecules were detected at 220 and $280 \mathrm{~nm}$. Mass measurements were performed in a positive mode with the mass range between 100 and $2000 \mathrm{~m} / \mathrm{z}$. Tentatively identified compounds were found based on the comparison of spectra with the ones reported in the literature.

\subsection{Antioxidant assays}

\subsubsection{DPPH radical scavenging activity assay}

The antioxidant activity was determined by free radical DPPH (2,2'-diphenyl-1-picrylhydrazyl) method proposed by Brand-Williams et al. (1995) with some modifications. To $0.1 \mathrm{~mL}$ of extract was added $3.9 \mathrm{~mL}$ of DPPH methanolic solution $(100 \mu \mathrm{M})$, a blank was prepared with methanol instead of sample, finally the mixture was stirred left in the dark for $30 \mathrm{~min}$. The absorbance of blend was measured at wavelength at $515 \mathrm{~nm}$. The result was expressed as percent inhibition of $\mathrm{DPPH} \bullet$ by the following Equation 1,

$$
\% \text { inhibition }=\left[1-\frac{A B}{A E}\right] \times 100
$$

where, $A B$ is the absorbance of sample and $A E$ is the absorbance of the blank.

For the determination of $\mathrm{IC}_{50}$ with $\mathrm{DPPH} \bullet$ radical, a curve between 5 to $100 \mu \mathrm{g} / \mathrm{mL}$ was used for the fruit extract and 1 to $20 \mu \mathrm{g} / \mathrm{mL}$ for leaf extracts and Trolox (6-Hydroxy-2,5,7,8-tetramethylchroman-2-carboxylic acid, chemical control). The $\mathrm{IC}_{50}$ was determined from the percent inhibition plot versus the sample concentration. The $\mathrm{IC}_{50}$ evaluations of the $\mathrm{DPPH} \bullet$ radical were performed in triplicate. 


\subsubsection{ABTS radical scavenging activity assay}

The antioxidant assay was determined according to method proposed by Ozgen et al. (2006). The ABTS reagent (2,2-azino-bis-3- ethylbenzothiazoline-6-sulfonic acid) was used, $2.45 \mathrm{mM}$ potassium persulfate solution was mixed with that of $7 \mathrm{mM}$ ABTS in water, the mixture was allowed to stand for $16 \mathrm{~h}$. The absorbance of ABTS ${ }^{\bullet+}$ radical solution was adjusted to $0.700 \pm 0.01$ at $734 \mathrm{~nm}$ by the addition of sodium acetate-acetic acid buffer ( $20 \mathrm{mM}$ at $\mathrm{pH} 4.5$ ). Finally, $0.1 \mathrm{~mL}$ of methanolic extract was added $2.9 \mathrm{~mL}$ of the solution containing the free radical ABTS ${ }^{\bullet}$, in addition to a blank without sample. The solutions were left in dark for $30 \mathrm{~min}$. The absorbance of the mixture was measured at $734 \mathrm{~nm}$. The result was expressed as percentage of inhibition of ABTS ${ }^{\bullet+}$ using Equation 1. For the IC $_{50}$ of ABTS ${ }^{\bullet+}$ a curve between 20 to $80 \mu \mathrm{g} / \mathrm{mL}$ was used for fruit extract and 10 to $30 \mu \mathrm{g} / \mathrm{mL}$ for leaf extract and Trolox. The $\mathrm{IC}_{50}$ was determined from the percent inhibition plot versus the sample concentration. The $\mathrm{IC}_{50}$ determinations of $\mathrm{ABTS}^{\bullet+}$ were performed in triplicate.

\subsubsection{Total phenolic content}

The analysis of total phenols was performed by spectrophotometry based on a colorimetric oxidationreduction reaction described by Ashraf et al. (2016) with some modifications. $0.1 \mathrm{~mL}$ of the methanolic extract $(2.4 \mathrm{mg} / \mathrm{mL})$ was added $1.6 \mathrm{ml}$ of distilled water, $0.4 \mathrm{~mL}$ of Folin-Ciocalteu reagent, $0.80 \mathrm{~mL}$ of $\mathrm{Na}_{2} \mathrm{CO}_{3}(10 \% \mathrm{w} / \mathrm{v})$ and $1.1 \mathrm{~mL}$ of water, the mixture was then left for $30 \mathrm{~min}$ at room temperature and in the dark, absorbances were measured at $765 \mathrm{~nm}$. The calibration curve was done with gallic acid (Sigma-Aldrich), between 0.25 to $20 \mathrm{mg} / \mathrm{L}$. The content of total phenols was expressed in mg EAG/g (mg equivalents of gallic acid per gram of dry extract).

\subsubsection{Total flavonoid content (flavone/flavonol)}

The total flavonoids content were determined by spectrophotometry based on the formation of a colored complex between $\mathrm{Al}$ (III) ions and carbonyl, and hydroxyl groups of flavonoid as described by Lillo et al. (2016). $0.1 \mathrm{~mL}$ of the methanolic extract $(2.4 \mathrm{mg} / \mathrm{mL})$ was added $0.2 \mathrm{~mL}$ of $\mathrm{AlCl}_{3}(2 \% \mathrm{w} / \mathrm{v})$ in ethanol, $0.2 \mathrm{~mL}$ of $1 \mathrm{M}$ sodium acetate and $3.5 \mathrm{~mL}$ methanol, the mixture was then left for $30 \mathrm{~min}$ at room temperature and in the dark, absorbances were measured at $425 \mathrm{~nm}$. The standard curve was made with quercetin (Sigma-Aldrich), between 0.0625 to $25 \mathrm{mg} / \mathrm{L}$. The content of total flavonoids was expressed in $\mathrm{mg}$ EQ/g ( $\mathrm{mg}$ equivalent of quercetin per gram of dry extract).

\subsubsection{Total condensed tannin content (proanthocyanidins)}

The contents of condensed tannins were measured according to the conditions of Price et al. (1978). An aliquot of $20 \mu \mathrm{L}(2.4 \mathrm{mg} / \mathrm{mL})$ of extract was added $180 \mu \mathrm{L}$ of methanol, mixed with $1.2 \mathrm{~mL}$ of $4 \% \mathrm{w} / \mathrm{v}$ vanillin in methanol, $600 \mu \mathrm{L}$ of $\mathrm{HCl}$ and reacted for $30 \mathrm{~min}$; the absorbance was determined at $500 \mathrm{~nm}$. A standard curve was established with (+)-catechin (Sigma-Aldrich), between 1 to $20 \mathrm{mg} / \mathrm{L}$. The content of total condensed tannins was expressed as $\mathrm{mg} \mathrm{EC} / \mathrm{g}$ (mg equivalent of catechin per gram of dry extract).

\subsubsection{Total alkaloid content}

The alkaloid content was evaluated by colorimetric method described by Nuñez et al. (2018). $5 \mathrm{~mL}$ of chloroform extract was taken and $5 \mathrm{~mL}$ of phosphate buffer $\mathrm{pH} 4.7$ and $5 \mathrm{~mL}$ of bromocresol green solution ( $34.9 \mathrm{mg}$ bromocresol green with $15 \mathrm{~mL}$ of $\mathrm{NaOH} 1 \mathrm{~N}$ ) were added, the mixture was transferred to a separating funnel, after three time liquid-liquid extractions with $2 \mathrm{~mL}$ of chloroform. The absorbance of the resulting organic phase was read at $470 \mathrm{~nm}$. The calibration curve was done with berberine (Sigma-Aldrich) from 2 to $10 \mathrm{mg} / \mathrm{L}$. The content of total alkaloids was expressed in $\mathrm{mg} \mathrm{EB} / \mathrm{g}$ (mg equivalents of berberine per gram of dry extract).

\subsubsection{Total lipid content}

The determination of the total lipids was made by the methodology proposed by Knight et al. (1972) with some modifications. Lipid quantification is performed by the Sulfo-Phosfo-Vanillin reagent(SFV), generating a stable pink colorimetric reaction between the carbonium ion derived from the unsaturated hydrocarbon chain of lipids and the aromatic phosphate ester (vanillin). The lyophilized sample was previously solubilized in methanol: chloroform: water $(2: 1: 0.8 \mathrm{v} / \mathrm{v} / \mathrm{v})$ to extract lipids. To $30 \mu \mathrm{L}$ of sample is added $270 \mu \mathrm{L}$ of concentrated sulfuric acid, the mixture is heated at $100{ }^{\circ} \mathrm{C}$ for $10 \mathrm{~min}$., cooled to room temperature and add $750 \mu \mathrm{l}$ of vanillin reagent (600 mg vanillin in $500 \mathrm{~mL}$ phosphoric acid), heat at $37^{\circ} \mathrm{C}$ for $15 \mathrm{~min}$. and cool to room temperature in darkness for $45 \mathrm{~min}$. The absorbance was determined at $530 \mathrm{~nm}$. The calibration curve was done with oleic acid from 1 to $50 \mathrm{mg} / \mathrm{L}$. The content of total lipids was expressed in $\mathrm{mg} \mathrm{OA} / \mathrm{g}$ ( $\mathrm{mg}$ equivalents of oleic acid per gram of dry extract).

\subsection{Antibacterial activity}

\subsubsection{Minimal inhibitory concentration (MIC)}

Antibacterial activity was evaluated by a liquid medium inhibitory growth of bacterial assay as described by Sutti et al. (2015). In a 96-well micro plate, $20 \mu \mathrm{L}$ of plant extract ( $4 \mathrm{mg} / \mathrm{mL}$ in DMSO $8 \% \mathrm{w} / \mathrm{v}$ ), were applied to wells of $80 \mu \mathrm{L}$ of the culture medium Poor Broth (PB) used for bacteria in the logarithmic phase of growth. The absorbance of the cultures was measured after $24 \mathrm{~h}$ incubation at $30^{\circ} \mathrm{C}$ on a microplate reader Victor3 (1420 Multilabel Counter/ Victor3 - Perkin Elmer) at $595 \mathrm{~nm}$.

The fruit and leaf extracts of $P$. lingue was tested against six bacterial strains, Gram-positive: Staphylococcus aureus ATCC 29213, Bacillus megaterium ATCC 10778 and Micrococcus luteus A270 and Gram-negative: Escherichia coli D31, Enterobacter cloacae $\beta 12$ and Pseudomonas aeruginosa ATCC 27853. The concentration range was 800 to $1.56 \mu \mathrm{g} / \mathrm{mL}$. Streptomycin was used as a positive control, and 8\% DMSO was also used as solvent control. MICs were expressed as the interval of concentrations [a]-[b], where [a] is the highest concentration tested at which the microorganisms were growing and [b] is the lowest concentration that causes $100 \%$ growth inhibition. All analyzes were performed in triplicate. 


\subsection{Cytotoxic activity}

\subsubsection{Cell lines and culture conditions}

The acute myeloblastic leukemia cell line Kasumi-1 and human acute T lymphocytic leukemia cell line Jurkat was cultured in suspension in RPMI 1640 medium (Cultilab, Brazil) supplemented with $10 \%$ fetal calf serum (FBS, Cultilab, Brazil), $100 \mathrm{U} / \mathrm{mL}$ penicillin, and $100 \mu \mathrm{g} / \mathrm{mL}$ streptomycin in a humidified atmosphere at $37^{\circ} \mathrm{C}$ under $5 \% \mathrm{CO}_{2}$.

\subsubsection{Propidium iodide (PI)/Calcein assay}

The cytotoxic activity was evaluated using the method propidium iodide/calcein described by Vermes et al. (1995) with some modifications. Cells of Kasumi- 1 and Jurkat were plated onto 96 -well microplates $\left(10^{5} \mathrm{cell} / \mathrm{mL}\right)$ in RPMI 1640 supplemented with $10 \%$ FBS in the absence or presence of the extracts $P$. lingue $(100 \mu \mathrm{g} / \mathrm{mL})$, for $48 \mathrm{~h}$ in a humidified atmosphere at $37{ }^{\circ} \mathrm{C}$ and $5 \% \mathrm{CO}_{2}$. After this period, the cells were washed with PBS and resuspended, to which $5 \mu \mathrm{g} /$ $\mathrm{mL}$ of PI and $1 \mu \mathrm{M}$ of calcein were added. The cells were incubated for $20 \mathrm{~min}$ at room temperature and protected from light. After incubation, the cells were washed with PBS and immediately analyzed on an Accuri C6 flow cytometer and Acurri C6 software. A total of 10,000 events were collected per sample. For the determination of the $\mathrm{EC}_{50}$ a curve was realized from 0.5 to $100 \mu \mathrm{g} / \mathrm{mL}$ for Jurkat, the $\mathrm{EC}_{50}$ is the concentration of extract that gives half-maximal response cell viability (\%), the $\mathrm{EC}_{50}$ value was calculated using a nonlinear regression curve.

\subsubsection{AlamarBlue assay}

This cytotoxic activity was evaluated using the method AlamarBlue described by Nakayama et al. (1997). The adherent cells of Jurkat and Kasumi-1, were plated onto 96 -well microplates $\left(2 \times 10^{4}\right.$ cells $\left./ \mathrm{mL}\right)$, and after $24 \mathrm{~h}$ were washed with PBS and subsequently incubated with the extracts of $P$. lingue $(100 \mu \mathrm{g} / \mathrm{mL})$ for $48 \mathrm{~h}$. After incubation, the medium was aspirated and $200 \mathrm{~mL}$ of sodium resazurin (Sigma-Aldrich, USA) solution prepared in culture medium without serum was added $(1 \mathrm{mg} / \mathrm{mL})$, the solution was in contact with the cells for $4 \mathrm{~h}$. Then, $100 \mu \mathrm{L}$ of the medium was transferred to 96 -well black plates and the reduction of resazurin was measured by fluorescence analysis $\left(\lambda_{\text {Ex. }}=560 \mathrm{~nm}, \lambda_{\text {Em. }}=590 \mathrm{~nm}\right)$ performed on a microplate reader FlexStation 3. Cell viability was normalized assuming control as $100 \%$.

\subsection{Statistic analysis}

All data collected for the chemical compounds were presented as the mean \pm standard deviation of at least three independent experiments and three replicates, for cytotoxic and antibacterial analysis with two independent experiments and three replicates. To determine if there were significant differences between the fruit and leaf extracts in each analyzes, a test t-student or test $\mathrm{W}$ of Mann-Whitney with a significance level of 95\% were employed. A non-parametric Kruskal-Wallis test was performed, with a significance level of 95\% to observe differences in the $\mathrm{IC}_{50}$ of $\mathrm{DPPH}^{+}$and $\mathrm{ABTS}^{\bullet+}$. A Spearman correlation was used between the antibacterial and cytotoxic variables with the chemical variables and between Antioxidant $\mathrm{DPPH}^{+}$and $\mathrm{ABTS}^{\bullet+}$ with the chemical variables. All analyses were performed with Statgraphic Centurion software.

\section{Results}

\subsection{Chemical analysis}

Analysis of the LC/ESI-MS results shows in the leaf extract (see Table 1), the presence of some types of polyphenolic compounds such as flavonoids derivative quercetin and kaempferol, as well as several condensed tannins; differing from the fruit extract, which contains few polyphenolic compounds and other no-identified compounds.

The antioxidant activities determined by DPPH and ABTS of $P$. lingue fruit and leaf extracts are presented in Figure 1. The amount of leaf extract to obtain an $\mathrm{IC}_{50}$ in the DPPH assay is statistically lower $(P<0.05)$ in relation to fruit extract ( 7.8 and $71.5 \mu \mathrm{g} / \mathrm{mL}$, respectively); in addition, the leaf extract has an approximate value for the chemical control Trolox. The same trend is observed for $\mathrm{IC}_{50}$ by the ABTS test, with a statistically significant difference $(P<0.05)$ between both extracts.

Table 1. ESI-MS product ions obtained from the $[\mathrm{M}-\mathrm{H}]^{+}$ions of extracts Persea lingue.

\begin{tabular}{|c|c|c|c|}
\hline Compound tentative & $\underset{(\mathbf{m i n})}{\mathbf{R T}}$ & {$[\mathbf{M}-\mathbf{H}]^{+}$} & $\begin{array}{c}\text { main } \\
\text { fragment }\end{array}$ \\
\hline \multicolumn{4}{|l|}{ Leaf } \\
\hline $\begin{array}{l}\text { Procyanidin trimer } \\
\text { type A }\end{array}$ & 14.86 & 865 & 713,291 \\
\hline Procyanidin tetramer & 14.17 & 1154 & $865,579,291$ \\
\hline Unknown & 15.08 & 305 & \\
\hline Rutin & 23.57 & 611 & 303 \\
\hline $\begin{array}{l}\text { Quercetina } \\
\text { 3-0-glucoside }\end{array}$ & 23.67 & 465 & 303 \\
\hline $\begin{array}{l}\text { Kaempferol } \\
\text { 3-O-glucoside }\end{array}$ & 25.15 & 449 & 327,287 \\
\hline $\begin{array}{l}\text { Ellagitannin } \\
\text { (elaeocarpusin) }\end{array}$ & 26.50 & 1111 & 303 \\
\hline Isorhamnetin & 27.37 & 317 & 287 \\
\hline \multicolumn{4}{|l|}{ Fruit } \\
\hline Unknown & 3.29 & 365 & \\
\hline Ellagic acid & 12.08 & 303 & \\
\hline Procyanidin trimer & 16.44 & 865 & 579 \\
\hline Unknown & 18.16 & 327 & \\
\hline Petunidin & 19.35 & 317 & \\
\hline (Epi)cathequingallate & 20.60 & 307 & 195 \\
\hline Unknown & 26.08 & 610 & 331 \\
\hline
\end{tabular}

RT: retention time. 
In the content of the different compounds analyzed, leaf extract of $P$. lingue showed a higher concentration of phenolics, flavonoids and condensed tannins (see Table 2), being statistically superior to extract of the fruit, which has a very low amount of total flavonoids and total condensed tannins. In the case of total alkaloids, the fruit extract has almost double the concentration of the leaf extract $(P<0.05)$. There is a high level of total lipids in the leaf and fruit, being in the latter almost 50\% higher $(P<0.05)$.

\subsection{Antibacterial activity}

MICs of leaf and fruit extracts of $P$. lingue is shown in Table 3. The differences in MIC values between the extracts of fruits and leaf are notable in most of bacteria tested, especially with E. coli, S. aureus and P. aureginosa, where the fruit extract has a high efficacy to inhibit the development of these microorganisms, with very lows MICs, while the leaf extract had no inhibitory effect in any concentration employed. Against B. megaterium and $M$. luteus, both extracts have inhibitory activity, but fruit extract is much more effective. The only bacterium whose growth was not inhibited by the two extracts was E. cloacae. Solvent control of 8\% DMSO showed no inhibition of bacterial growth.

\subsection{Cytotoxic activity}

The cytotoxic activity evaluated by PI/calcein assay, this methodology evaluate the cell membrane integrity, $P$. lingue extracts against Jurkat and Kasumi-1 cell (see Table 4) evidenced a better performance with the fruit

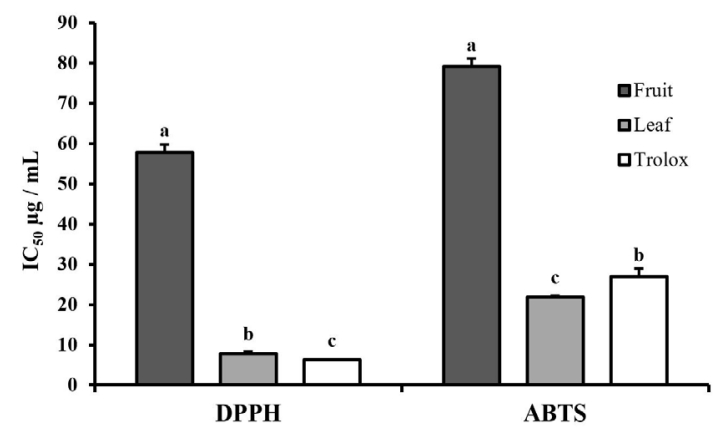

Figure 1. Antioxidant activity evaluated by DPPH and ABTS methods from fruit and leaf of Persea lingue extracts. Bars indicate mean value $\mathrm{IC}_{50}$ and respective standard deviation. Different letters indicate statistical difference, Kruskal-Wallis $(P<0.05, \mathrm{n}=3)$. Trolox chemical control. extract which showed an excellent effect on cellular viability levels. A statistical difference was observed with the leaf extracts that cause a small reduction in the cellular viability (62\% against Jurkat). For the Kasumi-1 cell, the fruit extract was again highlighted by the high cytotoxic activity, which had an effect on the cellular viability levels of approximately $2 \%$, whereas for the leaf extract the effect on the viability levels observed was $90 \%$, and therefore statistically inferior to the one observe with the fruit.

With AlamarBlue assay (see Table 4), which measure cell metabolism, the extracts present a similar behavior to the previous assay, although with lower levels of cytotoxic for the same cell lines. Fruit extract has a high cytotoxic activity causing a reduction in the cellular viability against Jurkat, and against Kasumi-1 cell. The fruit extract presented statistical difference $(\mathrm{P}<0.05)$ with the leaf extract.

The $\mathrm{EC}_{50}$ value for the fruit extract obtained from the concentration-response curve (see Figure 2) against the Jurkat cell is $5.5 \mu \mathrm{g} / \mathrm{mL}$ to obtain a $50 \%$ cell viability after $48 \mathrm{~h}$ of incubation, with the adjusted model equation: cell viability $(\%)=85.9579-17.8673 \times \ln ($ concentration $)$; $\mathrm{r}^{2}=0.9837$.

\section{Discussion}

\subsection{Chemical characterization}

Among the extracts of fruit and leaf of $P$. lingue, there is a clear differentiation in the antioxidant power that each one has and in the content of secondary metabolites. In general, phenolic compounds, have a high antioxidant power due to its chemical structure, which consists of at least one aromatic ring with a variable number of hydroxyl groups, which determine its antioxidant capacity (Balasundram et al., 2006), as well as the flavonoids (flavones, flavonols and proanthocyanidins) with various hydroxyl groups in their three rings, allow them to capture free radicals through the donation of hydrogen atoms (Procházková et al., 2011). Therefore, the high concentration of proanthocyanidins and flavones in leaf extract is what induce the high in vitro antioxidant power of this sample. Some of most common flavonoids in plants are the flavones quercetin and kaempferol. When they are methylated or glycosylated they form larger molecules as quercetin-3-O-glucoside, these flavones are possibly found in high concentrations in the leaf extract and also contains different types of proanthocyanidins. These observation corroborates with the highest index of the total phenols and flavonoids and the high antioxidant power,

Table 2. The content of total phenolics, flavonoids, condensed tannin, alkaloids and lipids from fruit and leaf Persea lingue extract.

\begin{tabular}{|c|c|c|c|c|c|}
\hline & Total Phenolics & Total Flavonoids* & $\begin{array}{l}\text { Total Condensed } \\
\text { Tannins* }\end{array}$ & Total Alkaloids & Total Lipids \\
\hline & (mg EAG/g) & (mg EQ/g) & $(\mathrm{mg} \mathrm{EC} / \mathrm{g})$ & (mg EB/g) & $(\mathrm{mg} \mathrm{OA} / \mathrm{g})$ \\
\hline Fruit & $2.032 \pm 0.051 b$ & $0.070 \pm 0.007 \mathrm{~b}$ & $0.177 \pm 0.036 b$ & $0.184 \pm 0.014 \mathrm{a}$ & $26.69 \pm 3.09 a$ \\
\hline Leaf & $4.863 \pm 0.115 a$ & $0.762 \pm 0.036 a$ & $2.221 \pm 0.139 a$ & $0.088 \pm 0.021 b$ & $16,41 \pm 1.14 \mathrm{~b}$ \\
\hline
\end{tabular}

Values indicate average and respective standard deviation. Different letters indicate statistical difference, t-student or W Man-Whitney* $(P<0.05)$. 
notoriously differentiating from the fruit extract. The former who concentrates another type of phytochemical like alkaloids and unsaturated lipids, the latter are abundant in fruits of the genus Persea (Dreher and Davenport 2013; Rodriguez-Saona et al., 2000). The concentrations of the phytochemicals, flavones and flavonols, present in the extracts had greater influence on the antioxidant power as observed in our study, for both DPPH and ABTS assays (Table 5). Possibly the other phenolic type compounds

Table 3. The minimum inhibitory concentration (MIC) of Persea lingue fruit and leaf extract against bacteria tested in microdilution assays.

\begin{tabular}{lccc}
\hline \multicolumn{1}{c}{ Bacteria } & & \multicolumn{2}{c}{ MIC $(\mu \mathrm{g} / \mathbf{m L})$} \\
\cline { 1 - 1 } \cline { 3 - 3 } \multicolumn{1}{c}{ Gram-Negative } & & Fruit & Leaf \\
\hline $\begin{array}{l}\text { Escherichia coli D31 } \\
\text { Pseudomonas aeruginosa }\end{array}$ & & $12.5-25$ & ND \\
ATCC 27853 & & ND \\
$\begin{array}{l}\text { Enterobacter cloacae } \beta 12 \\
\text { Gram-Positive }\end{array}$ & ND & ND \\
$\begin{array}{l}\text { Staphylococcus aureus ATCC } \\
\text { 29213 }\end{array}$ & $6.25-12.5$ & ND \\
$\begin{array}{l}\text { Bacillus megaterium ATCC } \\
10778\end{array}$ & $6.25-12.5$ & $200-400$ \\
Micrococcus luteus A270 & $3.12-6.25$ & $25-50$ \\
\hline
\end{tabular}

ND: not detected.

Table 4. Cytotoxic activity in cell lines Jurkat and Kasumi-1 with $\mathrm{PI} /$ Calcein and AlamarBlue assay, from fruit and leaf Persea lingue extract $(100 \mu \mathrm{g} / \mathrm{mL})$.

\begin{tabular}{lccc}
\hline & \multicolumn{3}{c}{ Cell Viability (\%) } \\
\cline { 2 - 4 } & Control & Fruit & Leaf \\
\hline PI/Calcein & & & \\
Jurkat & $96.7 \pm 1.2$ & $1.7 \pm 0.6 \mathrm{a}$ & $62.0 \pm 2.0 \mathrm{~b}$ \\
Kasumi-1 & $97.3 \pm 0.6$ & $2.0 \pm 1.0 \mathrm{a}$ & $90.0 \pm 2.6 \mathrm{~b}$ \\
AlamarBlue & & & \\
Jurkat & 100 & $7.1 \pm 0.8 \mathrm{a}$ & $83.8 \pm 3.5 \mathrm{~b}$ \\
Kasumi-1 & 100 & $46.7 \pm 1.8 \mathrm{a}$ & $89.3 \pm 3.3 \mathrm{~b}$ \\
\hline
\end{tabular}

Values indicate percent of viability cell and respective standard deviation. Different letters indicate statistical difference, $t$-student $(P<0.05)$. (condensed tannins, phenolic acids, hydroxycinnamic acids) also influence the antioxidant power, but in a lower extent.

\subsection{Antibacterial activity}

One of the properties of the secondary metabolites of plants is to provide protection against pathogens such as fungi, bacteria, and viruses. From our results of antibacterial activities, the extract that had the greatest efficacy against E. coli, S. aureus, M. luteus, B. megaterium and $P$. aeruginosa was the extract of the fruit, with MICs equal to or less than $12.5-25 \mu \mathrm{g} / \mathrm{mL}$. In contrast, leaf extract has activity only against $M$. luteus and $B$. megaterium, which is in agreement with that observed by Mølgaard et al. (2011), who did not find antibacterial activity against E. coli, S. aureus and P. aeruginosa in P. lingue leaf extract. However, Avello Lorca et al. (2012) found that P. lingue leaf oil has a mild antibacterial activity against $E$. coli, Bacillus subtillis, $P$. aeruginosa and $S$. aureus. Some investigations have found antimicrobial activity in the Persea americana extract against $P$. aeruginosa, E. coli and S. aureus (Raymond Chia and Dykes 2010; Rodríguez-Carpena et al., 2011). There are no studies so far regarding the antimicrobial activity of $P$. lingue fruit. The correlation analysis (see Table 5)

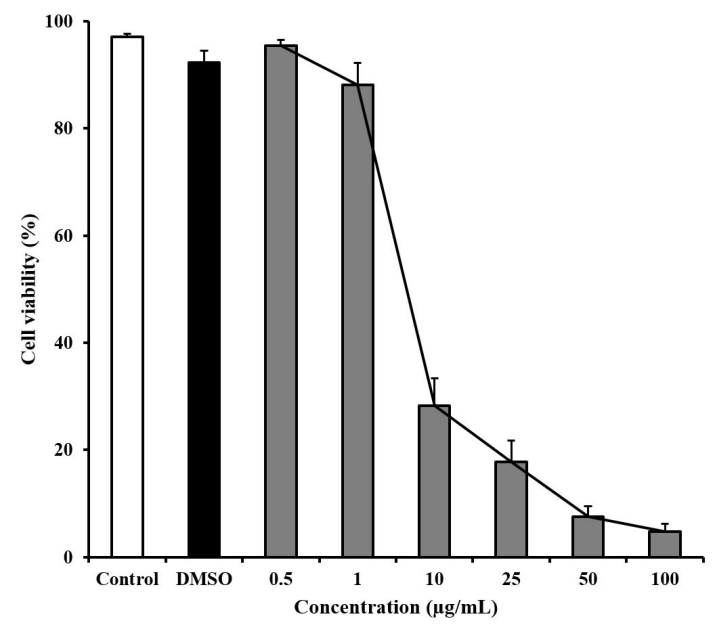

Figure 2. Concentration-response curve of Persea lingue fruit extract treatment of Jurkat cell line. $\mathrm{EC}_{50}$ obtained by curve fitting of viable cells after $48 \mathrm{~h}$ treatment for Jurkat cell line, cell viability $(\%)=85.9579-17.8673 \times \ln ($ concentration $) ; \mathrm{r}^{2}=0.9837$. Bars indicate mean value and respective standard deviation $(n=3)$.

Table 5. Spearman correlations: (a) between biological and chemical variables, (b) between antioxidant and chemical variables.

\begin{tabular}{|c|c|c|c|c|c|c|}
\hline & & Total Phenols & $\begin{array}{c}\text { Total } \\
\text { Flavonoids }\end{array}$ & $\begin{array}{c}\text { Total Tannin } \\
\text { condensed }\end{array}$ & Total Alkaloid & Total Lipids \\
\hline \multirow[t]{2}{*}{ (a) } & Cytotoxic & $-0.79^{* *}$ & $-0.76^{*}$ & $-0.73^{*}$ & $0.85^{* *}$ & $0.78^{*}$ \\
\hline & MIC & $-0.79^{* *}$ & $-0.88^{* *}$ & $-0.87^{* *}$ & $0.87^{* *}$ & $0.87^{* *}$ \\
\hline \multirow[t]{2}{*}{ (b) } & DPPH & ns & $0.88^{*}$ & ns & $-0.94^{*}$ & $-0.94^{*}$ \\
\hline & ABTS & $0.89^{*}$ & $0.88^{*}$ & ns & ns & -0.94 \\
\hline
\end{tabular}

${ }^{*}: P<0.05 ;{ }^{* *}: P<0.01 ;$ ns: not significant. 
suggests that antibacterial activity of the fruit is possibly mediated by the content of lipids or alkaloids and not by polyphenolic compounds.

The most important phytochemical compounds found in the $P$. lingue fruit have the potential to inhibit the development of Gram negative and Gram positive bacteria, possibly for presence of alkaloids. Thus some alkaloids as isoquinolines has been able to inhibit the cell function of bacteria through various mechanisms such as damaging the cell structure, causing Z-ring disturbance and inhibiting cell division. They also act as protein and DNA synthesis inhibitors that result in bacterial death. Isoquinoline can cause a remarkable increase in the DNA cleavage by targeting and inhibiting the bacterial topoisomerase IA. The quinolone alkaloid can inhibit type II topoisomerase enzymes and consequently, inhibit the DNA replication as well (Cushnie et al., 2014; Khameneh et al., 2019).

The lipids or fatty acids present in the fruit also have a high antibacterial potential, fatty acids are known to naturally insert into cell membranes and physically disturb their functionality, and cis-double bonds present in unsaturated fatty acids can form fixed bends in their carbon chain that occupy a greater cross-section and introduce disorder into neighbor phospholipid acyl chains, which leads to a greater fluidity of the membrane, generating cell disintegration (Salinas-Salazar et al., 2017).

\subsection{Cytotoxic activity}

From the first cytotoxicity analyzes by PI/calcein, observed against the Jurkat and Katsumi-1 cell, the fruit extract is notable for causing a high cell death, demonstrating its efficacy against these leukemia cell lines studied. Additionally, AlamarBlue assay, also showed a high cytotoxic activity against the Jurkat cell. There is evidence that leafs and seeds of the P. americana species have cytotoxic properties against the Jurkat cell (BonillaPorras et al., 2013), which is in agreement with the data obtained with $P$. lingue fruit in this study. A crude extract is generally considered to have in vitro cytotoxic activity, if the $\mathrm{EC}_{50}$ value following incubation between 48 and $72 \mathrm{~h}$ is less than $20 \mu \mathrm{g} / \mathrm{mL}$ (Lee and Houghton 2005). Therefore, the fruit extract has a high potential for cytotoxic activity against the Jurkat cell due to the low $\mathrm{EC}_{50}$ value obtained $(5.5 \mu \mathrm{g} / \mathrm{mL})$, that can be considered very active (Nordin et al., 2018).

Some researchers have also found a positive correlation between antioxidant power and anticancer activity of plant extracts (Li et al., 2007; Wang et al., 2007). However with $P$. lingue species, the opposite was observed, may be due to the low antioxidant activity found in the fruit, indicating that anticancer potential of this species is not due to phenolic compounds or another compounds with high antioxidant power (as show in Table 5). It is important to consider that many species belonging to the genus Persea contain lipidic compounds like avocadofurans and acetogenins, which are present in the bark, leaves and fruits of these species. These compounds provide a high biological activity such as antimicrobial, insecticidal, anticancer, antithrombotic, and others (Yasir et al., 2010; Ma et al., 1989, 1990; Reis et al., 2019; Fraga and Terrero
1996; Rodriguez-Saona et al., 2000; Rodriguez-Saona and Trumble, 2000; Domergue et al., 2000; Scora and Scora 2001; Pino et al., 2004; Butt et al., 2006; RodriguezSanchez et al., 2015). Therefore, it is possible that the high antibacterial and especially cytotoxic activity detected in the $P$. lingue fruit may be due to the presence of some of these phytochemicals, which is found in high quantity of lipids in the fruit and with an important positive correlation (see Table 5).

It is important to evaluate the level of cytotoxicity of the extracts to observe if the phytochemicals present in $P$. lingue fruit do not significantly damage normal cells, which is essential for their potential therapeutic use.

\section{Conclusions}

The Persea lingue fruit is a potential source of biologically active molecules for development of new drugs to be used in some types of leukemia, as well as antibacterial agent. This study is one of the first contributions and possibly the only one to investigate the anticancer and antibacterial properties, and the chemical characterization of this plant.

\section{Acknowledgements}

The authors thank Dr. Rolando Díaz of the University of La Frontera for his help in the collection and identification of plant samples; and FAPESP-CeTICS/CEPID - [Grant No.2013/07467-1] and CNPQ - [Grant No. 472744/2012-7].

\section{References}

ASHRAF, A., SARFRAZ, R.A., RASHID, M.A., MAHMOOD, A., SHAHID, M. and NOOR, N., 2016. Chemical composition, antioxidant, antitumor, anticancer and cytotoxic effects of Psidium guajava leaf extracts. Pharmaceutical Biology, vol. 54, no. 10, pp. 19711981. http://dx.doi.org/10.3109/13880209.2015.1137604. PMid:26841303.

AVELLO LORCA, M., LÓPEZ CANALES, C., GATICA VALENZUELA, C., BUSTOS CONCHA, E., BRIEVA CHAIT, A., PASTENE NAVARRETE, E.C. and BITTNER BERNER, M.C., 2012. Efectos antimicrobianos de extractos de plantas Chilenas de las familias Lauraceae y Atherospermataceae. Revista Cubana de Plantas Medicinales, vol. 17, no. 1, pp. 73-83.

BALASUNDRAM, N., SUNDRAM, K. and SAMMAN, S., 2006. Phenolic compounds in plants and agri-industrial by-products: antioxidant activity, occurrence, and potential uses. Food Chemistry, vol. 99, no. 1, pp. 191-203. http://dx.doi.org/10.1016/j. foodchem.2005.07.042

BONILLA-PORRAS, A.R., SALAZAR-OSPINA, A., JIMENEZ-DEL-RIO, M., PEREAÑEZ-JIMENEZ, A. and VELEZ-PARDO, C., 2013. Proapoptotic effect of Persea americana var. Hass (avocado) on Jurkat lymphoblastic leukemia cells. Pharmaceutical Biology, vol. 52, no. 4, pp. 458-465. http://dx.doi.org/10.3109/138802 09.2013.842599. PMid:24188375.

BRAND-WILLIAMS, W., CUVELIER, M.E. and BERSET, C., 1995. Use of a free radical method to evaluate antioxidant activity. Lebensmittel-Wissenschaft + Technologie, vol. 28, no. 1, pp. 25-30. http://dx.doi.org/10.1016/S0023-6438(95)80008-5. 
BUTT, A.J., ROBERTS, C.G., SEAWRIGHT, A.A., OELRICHS, P.B., MACLEOD, J.K., LIAW, T.Y.E., KAVALLARIS, M., SOMERS-EDGAR, T.J., LEHRBACH, G.M., WATTS, C.K. and SUTHERLAND, R.L., 2006. A novel plant toxin, persin, with in vivo activity in the mammary gland, induces Bim-dependent apoptosis in human breast cancer cells. Molecular Cancer Therapeutics, vol. 5, no. 9, pp. 2300-2309. http://dx.doi.org/10.1158/1535-7163.MCT-060170. PMid:16985064.

CHILE. Ministerio Del Medio Ambiente De Chile - MMA, 2019 [viewed 24 September 2019]. Inventario Nacional de Especies de Chile, [online]. Available from: https://especies.mma.gob.cl.

COB, J.V., SABJA, A.M., RÍOS, D., LARA, A., DONOSO, P.J., ARIAS, L. and ESCOBAR, B., 2010. Potencial de la organogénesis como estrategia para la masificación in vitro de Persea lingue en la zona centro-sur de Chile. Bosque (Valdivia), vol. 31, no. 3, pp. 202208. http://dx.doi.org/10.4067/S0717-92002010000300004.

CUSHNIE, T.P., CUSHNIE, B. and LAMB, A.J., 2014. Alkaloids: an overview of their antibacterial, antibiotic-enhancing and antivirulence activities. International Journal of Antimicrobial Agents, vol. 44, no. 5, pp. 377-386. http://dx.doi.org/10.1016/j. ijantimicag.2014.06.001. PMid:25130096.

DELGODA, R. and MURRAY, J.E., 2017. Evolutionary perspectives on the role of Plant secondary metabolites. In: S. BADAL and R. DELGODA, eds. Pharmacognosy: fundamentals, applications and strategies. London: Academic Press, pp. 93-100. https:// doi.org/10.1016/B978-0-12-802104-0.00007-X.

DOMERGUE, F., HELMS, G.L., PRUSKY, D. and BROWSE, J., 2000. Antifungal compounds from idioblast cells isolated from avocado fruits. Phytochemistry, vol. 54, no. 2, pp. 183-189. http:// dx.doi.org/10.1016/S0031-9422(00)00055-8. PMid:10872209.

DONOSO, C. and ESCOBAR, B., 2006. Persea lingue. In: C.D. ZEGERS, ed. Las especies arbóreas de los bosques templados de Chile y Argentina. Valdivia: Marisa Cuneo Eds., pp. 501-509.

DREHER, M.L. and DAVENPORT, A.J., 2013. Hass Avocado composition and potential health effects. Critical Reviews in Food Science and Nutrition, vol. 53, no. 7, pp. 738-750. http://dx.doi.org/10.1080 /10408398.2011.556759. PMid:23638933.

ELISHA, I.L., BOTHA, F.S., MCGAW, L.J. and ELOFF, J.N., 2017. The antibacterial activity of extracts of nine plant species with good activity against Escherichia coli against five other bacteria and cytotoxicity of extracts. BMC Complementary and Alternative Medicine, vol. 17, no. 1, pp. 133. http://dx.doi.org/10.1186/ s12906-017-1645-z. PMid:28241818.

FRAGA, B.M. and TERRERO, D., 1996. Alkene- $\gamma$-lactones and avocadofurans from Persea indica: a revision of the structure of majorenolide and related lactones. Phytochemistry, vol. 41, no. 1, pp. 229-232. http://dx.doi.org/10.1016/0031-9422(95)00518-8.

FREIESLEBEN, S.H. and JÄGER, A.K., 2014. Correlation between plant secondary metabolites and their antifungal mechanisms-A Review. Medicinal E Aromatic Plants, vol. 3, no. 2, pp. 2014. http://dx.doi.org/10.4172/2167-0412.1000154.

FULDA, S. and EFFERTH, T., 2015. Selected secondary plant metabolites for cancer therapy. World Journal of Traditional Chinese Medicine, vol. 1, no. 1, pp. 24-28. http://dx.doi. org/10.15806/j.issn.2311-8571.2014.0005.

GHO-ILLANES, D., SMITH-RAMÍREZ, C., VÁSQUEZ, I.A. and DÍAZ, I., 2015. Frugivory of Persea lingue (Lauraceae) and its effect on seed germination in southern Chile. Gayana. Botánica, vol. 72, no. 2, pp. 250-257. http://dx.doi.org/10.4067/S071766432015000200009 .

GUZMÁN-RODRÍGUEZ, J.J., LÓPEZ-GÓMEZ, R., SUÁREZ-RODRÍGUEZ, L.M., SALGADO-GARCIGLIA, R., RODRÍGUEZ-ZAPATA, L.C., OCHOA-ZARZOSA, A. and LÓPEZ-MEZA, J.E., 2013. Antibacterial activity of defensin PaDef from Avocado fruit (Persea americana var. drymifolia) expressed in endothelial cells against Escherichia coli and Staphylococcus aureus. BioMed Research International, vol. 2013, pp. 1-9. http://dx.doi.org/10.1155/2013/986273. PMid:24319695.

HOLLER, J.G., CHRISTENSEN, S.B., SLOTVED, H.C., RASMUSSEN, H.B., GUZMAN, A., OLSEN, C.E., PETERSEN, B. and MOLGAARD, P., 2012a. Novel inhibitory activity of the Staphylococcus aureus NorA efflux pump by a kaempferol rhamnoside isolated from Persea lingue Nees. The Journal of Antimicrobial Chemotherapy, vol. 67, no. 5, pp. 1138-1144. http://dx.doi.org/10.1093/jac/ dks005. PMid:22311936.

HOLLER, J.G., SøNDERGAARD, K., SLOTVED, H.C., GÚZMAN, A. and MØLGAARD, P., 2012b. Evaluation of the antibacterial activity of Chilean plants traditionally used for wound healing therapy against multidrug-resistant Staphylococcus aureus. Planta Medica, vol. 78, no. 2, pp. 200-205. http://dx.doi. org/10.1055/s-0031-1280316. PMid:22083898.

JESUS, D., OLIVEIRA, J.R., OLIVEIRA, F.E., HIGA, K.C., JUNQUEIRA, J.C., JORGE, A.O.C., BACK-BRITO, G.N. and OLIVEIRA, L.D., 2015. Persea americana glycolic extract: in vitro study of antimicrobial activity against Candida albicans biofilm and cytotoxicity evaluation. The Scientific World Journal, vol. 2015, pp. 531972. http://dx.doi. org/10.1155/2015/531972. PMid:26605376.

KENNEDY, D.O. and WIGHTMAN, E.L., 2011. Herbal Extracts and Phytochemicals: plant secondary metabolites and the enhancement of human brain function. Advances in Nutrition, vol. 2, no. 1, pp. 32-50. http://dx.doi.org/10.3945/an.110.000117. PMid:22211188.

KHAMENEH, B., IRANSHAHY, M., SOHEILI, V. and FAZLY BAZZAZ, B.S., 2019. Review on plant antimicrobials: a mechanistic viewpoint. Antimicrobial Resistance and Infection Control, vol. 8, no. 1, pp. 118. http://dx.doi.org/10.1186/s13756-019-0559-6. PMid:31346459.

KNIGHT, J.A., ANDERSON, S. and RAWLE, J.M., 1972. Chemical basis of the sulfo-phospho-vanillin reaction for estimating total serum lipids. Clinical Chemistry, vol. 18, no. 3, pp. 199-202. http://dx.doi.org/10.1093/clinchem/18.3.199. PMid:5020813.

LEE, C.C. and HOUGHTON, P., 2005. Cytotoxicity of plants from Malaysia and Thailand used traditionally to treat cancer.Journal of Ethnopharmacology, vol. 100, no. 3, pp. 237-243. http://dx.doi. org/10.1016/j.jep.2005.01.064. PMid:15888378.

LI, W.Y., CHAN, S.W., GUO, D.J. and YU, P.H.F., 2007. Correlation between antioxidative power and anticancer activity in herbs from traditional Chinese medicine formulae with anticancer therapeutic effect. Pharmaceutical Biology, vol. 45, no. 7, pp. 541-546. http://dx.doi.org/10.1080/13880200701498879.

LILLO, A., CARVAJAL-CAICONTE, F., NUÑEZ, D., BALBOA, N. and ALVEARZAMORA, M., 2016. Cuantificación espectrofotométrica de compuestos fenólicos y actividad antioxidante en distintos berries nativos del Cono Sur de América. Revista Investigación Agropecuaria, vol. 4, no. 2, pp. 168-174.

LIMA, C.R., VASCONCELOS, C.F.B., COSTA-SILVA, J.H., MARANHÃO, C.A., COSTA, J., BATISTA, T.M., CARNEIRO, E.M., SOARES, L.A.L., FERREIRA, F. and WANDERLEY, A.G., 2012. Anti-diabetic activity of extract from Persea americana Mill. leaf via the activation of protein kinase $\mathrm{B}$ (PKB/Akt) in streptozotocin-induced diabetic rats. Journal of Ethnopharmacology, vol. 141, no. 1, pp. 517-525. http://dx.doi.org/10.1016/j.jep.2012.03.026. PMid:22472105.

MA, W.W., ANDERSON, J.E., CHANG, C.J., SMITH, D.L. and MCLAUGHLIN, J.L., 1989. Majorenolide and Majorynolide: a new pair of cytotoxic and pesticidal alkene-alkyne $\delta$-lactones from Persea major. Journal of Natural Products, vol. 52, no. 6, pp. 12631266. http://dx.doi.org/10.1021/np50066a011. PMid:2614421. 
MA, W.W., ANDERSON, J.E., CHANG, C.J., SMITH, D.L. and MCLAUGHLIN, J.L., 1990. Majoranolide: a $\delta$-lactone from Persea major. Phytochemistry, vol. 29, no. 8, pp. 2698-2699. http:// dx.doi.org/10.1016/0031-9422(90)85218-5.

MøLGAARD, P., HOLLER, J.G., ASAR, B., LIBERNA, B., ROSENB/K, L.B., JEBJERG, C.P., JøRGENSEN, L., LAURITZEN, J., GUZMAN, A., ADSERSEN, A. and SIMONSEN, H.T., 2011. Antimicrobial evaluation of Huilliche plant medicine used to treat wounds. Journal of Ethnopharmacology, vol. 138, no. 1, pp. 219-227. PMid: 21939748.

NAKAYAMA, G.R., CATON, M.C., NOVA, M.P. and PARANDOOSH, Z., 1997. Assessment of the Alamar Blue assay for cellular growth and viability in vitro. Journal of Immunological Methods, vol. 204 , no. 2, pp. 205-208. http://dx.doi.org/10.1016/S00221759(97)00043-4. PMid:9212838.

NORDIN, M.L., ABDUL KADIR, A., ZAKARIA, Z.A., ABDULLAH, R. and ABDULLAH, M.N.H., 2018. In vitro investigation of cytotoxic and antioxidative activities of Ardisia crispa against breast cancer cell lines, MCF-7 and MDA-MB-231. BMC Complementary and Alternative Medicine, vol. 18, no. 1, pp. 87. http://dx.doi. org/10.1186/s12906-018-2153-5. PMid:29530022.

NÚÑEZ, D., BALBOA, N., CARVAJAL, F., ALVEAR, M. and PAREDES, M., 2018. Efecto del extracto de alcaloides de Berberis darwinii Hook sobre respuestas celulares innatas en fagocitos murinos. Boletín Latinoamericano y del Caribe de Plantas Medicinales y Aromáticas, vol. 17, no. 3, pp. 259-269.

OZGEN, M., REESE, R.N., TULIO JUNIOR, A.Z., SCHEERENS, J.C. and MILLER, A.R., 2006. Modified 2,2-azino-bis-3ethylbenzothiazoline-6-sulfonic acid (ABTS) method to measure antioxidant capacity of selected small fruits and comparison to ferric reducing antioxidant power (FRAP) and 2,2 -diphenyl-1- picrylhydrazyl (DPPH) methods. Journal of Agricultural and Food Chemistry, vol. 54, no. 4, pp. 1151-1157. http://dx.doi.org/10.1021/jf051960d. PMid:16478230.

PALAZZO, M.C., AGIUS, B.R., WRIGHT, B.S., HABER, W.A., MORIARITY, D.M. and SETZER, W.N., 2009. Chemical compositions and cytotoxic activities of leaf essential oils of four Lauraceae tree species from Monteverde, Costa Rica. Records of Natural Products, vol. 3, no. 1, pp. 32-37.

PARDO, O. and PIZARRO, J.L., 2016. Chile. Bebidas Fermentadas Prehispanicas. Arica: Ediciones Parina EIRL. 191 p.

PINO, J.A., FERNANDES, P., MARBOT, R., ROSADO, A. and FONTINHA, S.S., 2004. Leaf oils of Helichrysum melaleucum Rchb. ex Holl., Oenanthe divaricata (R. Br.) Mabb. and Persea indica (L.) Spreng. from Madeira. The Journal of Essential Oil Research, vol. 16, no. 5, pp. 487-489. http://dx.doi.org/10.1080/10412905.2004.9698778.

PRICE, M.L., VAN SCOYOC, S. and BUTLER, L.G., 1978. A critical evaluation of the vanillin reaction as an assay for tannin in sorghum grain. Journal of Agricultural and Food Chemistry, vol. 26, no. 5, pp. 1214-1218. http://dx.doi.org/10.1021/jf60219a031.

PROCHÁZKOVÁ, D., BOUŠOVÁ, I. and WILHELMOVÁ, N., 2011. Antioxidant and prooxidant properties of flavonoids. Fitoterapia, vol. 82, no. 4, pp. 513-523. http://dx.doi.org/10.1016/j. fitote.2011.01.018. PMid:21277359.

RAYMOND CHIA, T.W. and DYKES, G.A., 2010. Antimicrobial activity of crude epicarp and seed extracts from mature avocado fruit (Persea americana) of three cultivars. Pharmaceutical Biology, vol. 48, no. 7, pp. 753-756. http://dx.doi. org/10.3109/13880200903273922. PMid:20645772.

REIS, I.M.A., CONCEIÇÃO, R.S., FERREIRA, R.S., DOS SANTOS, C.C., DA SILVA, G.R., DE MATTOS OLIVEIRA, L., CASSIANO, D.S.A., DOS SANTOS JUNIOR, M.C., BOTURA, M.B., DA SILVA, V.D.A., COSTA, S.L., DA SILVA, T.M.S., VIEIRA, I.J.C., BRAZ-FILHO, R. and BRANCO, A., 2019. Alkene lactones from Persea fulva (Lauraceae): evaluation of their effects on tumor cell growth in vitro and molecular docking studies. Bioorganic Chemistry, vol. 86, pp. 665-673. http://dx.doi.org/10.1016/j.bioorg.2019.02.023. PMid:30826627.

RODRÍGUEZ-CARPENA, J.G., MORCUENDE, D., ANDRADE, M.J., KYLLI, P. and ESTÉVEZ, M., 2011. Avocado (Persea americana Mill.) phenolics, in vitro antioxidant and antimicrobial activities, and inhibition of lipid and protein oxidation in porcine patties. Journal of Agricultural and Food Chemistry, vol. 59, no. 10, pp. 5625-5635. http://dx.doi.org/10.1021/jf1048832. PMid:21480593.

RODRIGUEZ-SANCHEZ, D.G., FLORES-GARCÍA, M., SILVA-PLATAS, C., RIZZO, S., TORRE-AMIONE, G., DE LA PEÑA-DIAZ, A., HERNÁNDEZ-BRENES, C. and GARCÍA-RIVAS, G., 2015. Isolation and chemical identification of lipid derivatives from avocado (Persea americana) pulp with antiplatelet and antithrombotic activities. Food E Function, vol. 6, no. 1, pp. 193-202. http:// dx.doi.org/10.1039/C4FO00610K. PMid:25319210.

RODRIGUEZ-SAONA, C. and TRUMBLE, J., 2000. Biologically active aliphatic acetogenins from specialized idioblast oil cells. Current Organic Chemistry, vol. 4, no. 12, pp. 1249-1260. http://dx.doi. org/10.2174/1385272003375789.

RODRIGUEZ-SAONA, C., MAYNARD, D.F., PHILLIPS, S. and TRUMBLE, J.T., 2000. Avocadofurans and their tetrahydrofuran analogues: comparison of growth inhibitory and insecticidal activity. Journal of Agricultural and Food Chemistry, vol. 48, no. 8, pp. 3642-3645. http://dx.doi.org/10.1021/jf9910638. PMid:10956163.

SALINAS-SALAZAR, C., HERNÁNDEZ-BRENES, C., RODRÍGUEZSÁNCHEZ, D.G., CASTILLO, E.C., NAVARRO-SILVA, J.M. and PACHECO, A., 2017. Inhibitory activity of avocado seed fatty acid derivatives (acetogenins) against Listeria Monocytogenes. Journal of Food Science, vol. 82, no. 1, pp. 134-144. https://doi. org/10.1111/1750-3841.13553.

SCORA, R.W. and SCORA, P.E., 2001. Essential leaf oil of Persea Subgenus Eriodaphne and closely related Perseoid genera. The Journal of Essential Oil Research, vol. 13, no. 1, pp. 37-42. http:// dx.doi.org/10.1080/10412905.2001.9699599.

SUTTI, R., ROSA, B.B., WUNDERLICH, B., DA SILVA JUNIOR, P.I. and ROCHA E SILVA, T.A.A.D.. 2015. Antimicrobial activity of the toxin VdTX-I from the spider Vitalius dubius (Araneae, Theraphosidae). Biochemistry and Biophysics Reports, vol. 4, pp. 324-328. http://dx.doi.org/10.1016/j.bbrep.2015.09.018. PMid:29124220.

VAN DER WERFF, H., 2002. A synopsis of Persea (Lauraceae) in Central America. Novon, vol. 12, no. 4, pp. 575-586. http:// dx.doi.org/10.2307/3393142.

VERGARA, P.M., SMITH, C., DELPIANO, C.A., ORELLANA, I., GHO, D. and VAZQUEZ, I., 2010. Frugivory on Persea lingue in temperate Chilean forests: interactions between fruit availability and habitat fragmentation across multiple spatial scales. Oecologia, vol. 164, no. 4, pp. 981-991. http://dx.doi.org/10.1007/s00442010-1722-1. PMid:20697745.

VERMES, I., HAANEN, C., STEFFENS-NAKKEN, H. and REUTELINGSPERGER, C., 1995. A novel assay for apoptosis Flow cytometric detection of phosphatidylserine expression on early apoptotic cells using fluorescein labelled Annexin V. Journal of Immunological Methods, vol. 184, no. 1, pp. 39-51. http://dx.doi. org/10.1016/0022-1759(95)00072-I. PMid:7622868.

WANG, S.Y., LEWERS, K.S., BOWMAN, L. and DING, M., 2007. Antioxidant activities and anticancer cell proliferation properties of wild strawberries. Journal of the American Society for Horticultural Science, vol. 132, no. 5, pp. 647-658. http:// dx.doi.org/10.21273/JASHS.132.5.647. 
Lillo, A. et al.

WINK, M., 2003. Evolution of secondary metabolites from an ecological and molecular phylogenetic perspective. Phytochemistry, vol. 64, no. 1, pp. 3-19. http://dx.doi.org/10.1016/ S0031-9422(03)00300-5. PMid:12946402.
YASIR, M., DAS, S. and KHARYA, M., 2010. The phytochemical and pharmacological profile of Persea americana Mill. Pharmacognosy Reviews, vol. 4, no. 7, pp. 77-84. http://dx.doi.org/10.4103/09737847.65332. PMid:22228945. 